\title{
セメントモルタルに對する酸液の作用 (第一報)
}

\author{
永井彰 一 郎
}

\section{I 緒 言}

セメントの水硬素は珪酸石灰監及び攀土酸石灰鹽の如き鹽基性化合物なるを以つて酸液に㑐つ て極めて犯され易く、從つて此のセメントを使用したるモルタル又はコンクリートの是等酸液に 對する抵抗性は極品て微弱なり。故に硫酸、鹽酸、硝酸等の無機酸及び热種の有機酸を取扱心化 學工場に於けるコンクリート工事或は溫泉水。地下水等の酸性水に直接する土木、建築等のコン クリート等に於ては他の籃類と共に酸類の爲め隻蝕を受け易きものなり。

本研究に於ては本邦製セメントの中其の成分、性質を異にせる3種のセメント即ち混合セメント より高爐セメントとソリヂチットの 2 種、ポルトランドセメントより 1 種を取りて試料とし僽種の

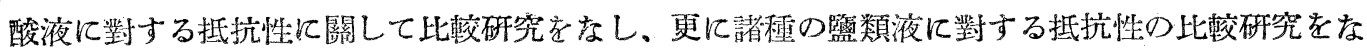
さんとするるのなり。是等の酸液、鹽液に對してはアルミナセメントは抵抗性大なるべきる本邦 に於ては未代其の製造を見ざるを以つて前記 3 種類の本邦製セメントに限り、ポルトランドセメ ントが抵抗性最も微弱なるに對して何等かの改善法に就いても併せて研究せんとするものなり。 本報には其の第一報として無機酸液の作用に關して3種のセメントのモルタルに對する比較研究 結果の一部を報告したるものなり。

\section{II セメント試料の一般試驗}

本報の研宪試料に供したるセメントは九州八幡製鐵所化工部の製品高爐セメント及び東京月島 日本ソリヂチット株式會枉製ソリヂチットの 2 種の混合セメントと、ポルトランドセメントとして は整城セメント株式會社製ポルトランドセメントの 3 種なり是等 3 種のセメント試料に就いて本 報の研究に先立ち、其の化學成分、物理性等に關して試驗したる結果を表示すべし。

(1) セポト試料の化學成分

第一表 セメント試料の化學成分分析表

\begin{tabular}{|c|c|c|c|c|c|c|c|c|}
\hline せメント種别 & 灼熱 & 不溶分 & 王酸 & 攀土 & 酸化鐵 & 石灰 & 苦士 & アルカリ \\
\hline 高爐七メント & $0.35 \%$ & $0.26 \%$ & $28.36 \%$ & $10.57 \%$ & $2.20 \%$ & $52.38 \%$ & $2.43 \%$ & $1.47 \%$ \\
\hline リヂチッ & 1.26 & 23.85 & 35.19 & 5.06 & 4.45 & 50.07 & 1.23 & 1.93 \\
\hline (1) $\rightarrow$ & 1.48 & 0.62 & 21.58 & 5.28 & 3.46 & 65.25 & 1.56 & - \\
\hline
\end{tabular}

向高爐セメントには酸化滿俺 $0.77 \%$ 、硫化物型硫黃 $0.42 \%$ を含むるのなり。此の結果に就い

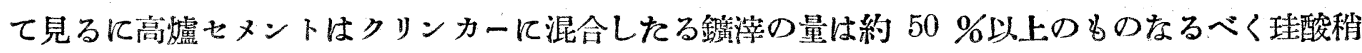
多く、石灰稍少量なり。之に對して最近の高爐七メントは鐄涬の混合量は $50 \%$ 以內にて約 $40 \%$ 
位なりといふ。從つて珪酸少く石灰多くして鐵ポルトランドセメントに近似しつ〉あるを認む。 (著者報告：本邦セメントの試驗報告參照)。斯くの如く高爐セメントは最近强度に於ては著しく 進步したりと踓も他面に於ては高爐セメントの高爐セメントたるた特質次第に薄らぐの感無き能 はざるは遺憾とするとてろなり。後節に於ける酸液に對する抵抗性が高爐セヌントに於いて最も 優良なるが如き特性を捨てつ唯强度に於てのみポルトランドセメントと競ふてとは深く考究を要 すべきものと信ず。

ソリヂチットは花崗岩焙燒物の粉末の混用に依り全珪酸は大量なりと踓 し其の約牛分は不溶性 珪酸又は長石質の不溶分なるを以つて徒らにクリンカー中の稀釋材となるのみにして酸液に對す る抵抗性の改善とはならずしてポルトランドセメントにも優れざるが如きるのなるてとは後節の 酸液に依る抵抗性の比較試驗に依りて明らかなり。

ポルトランドセメントは石灰最も多く即ち鹽基性最も著しきセメントなる安以つて酸液に對す る抵抗性の最も微弱なるは略想像に難からざるものなり。

\section{（2） セメント試料の比重乙粉末度}

第二表 セメント試料の比重。粉末度試驗絬果

\begin{tabular}{|c|c|c|c|c|c|c|}
\hline \multirow[b]{2}{*}{ セメント種别 } & 比 & 重 & \multicolumn{4}{|c|}{ 粉 未 度 (節别殘椬) } \\
\hline & （其儘） & (灼熱後) & 900 & 目節殘椬\% & 2500 目笽殘渣 $\%$ & 4900 目篩殘渣 $\%$ \\
\hline 高爐セメント & 2.92 & 3.02 & & 0.53 & 2.27 & 8.73 \\
\hline ソリヂチット & 2.91 & 3.02 & & 0.87 & 4.54 & $\mathbf{1 4 . 3 0}$ \\
\hline 䑾城セメント & 3.06 & 3.22 & & 0.09 & 1.37 & 7.94 \\
\hline
\end{tabular}

即ち此の結果に依えば混合セメントなる亳罏セメントとソリヂチットとは共に比重稍小にして （ポルトランドセメント規格の3.05以上の大なるに對して）2.85(高賟セメント規格)の規格以上 なれども何 2.91〜2.92 の數值なるに過ざす。粉末度は最近の本邦セメントに比すれば稍粗なれど る本報研究開咍當時の製品としては普通なり。

（3）セメントモルタルの强度 日本新標準砂を使用し新規格に準じて嚴密に比較試驗したる1:3 セメントモルタルの强度試驗結果は次の第三表の如し。

$$
\text { 第三表 セメントモルタルの强度試驗結果 }
$$

\begin{tabular}{|c|c|c|c|c|c|c|}
\hline \multirow[b]{2}{*}{ セメント種别 } & \multicolumn{2}{|c|}{ 抗張力 $\left(\mathrm{kg} / \mathrm{cm}^{2}\right)$} & \multicolumn{2}{|c|}{ 耐赝力 $\left(\mathrm{kg} / \mathrm{cm}^{2}\right)$} & \multicolumn{2}{|c|}{ 脆度係數(酎熦力抗張力 } \\
\hline & 1 週 & 4 週 & 1 週 & 4 週 & 1 洞 & 4 週 \\
\hline 高爐セメント & 27.6 & 33.3 & 254 & 326 & 9.21 & 9.79 \\
\hline ソリヂチット & 26.5 & 28.7 & 276 & 335 & 10.4 & 11.7 \\
\hline 磐战セメント & 25.0 & 32.1 & 310 & 381 & 12.4 & 11.9 \\
\hline
\end{tabular}

此の結果に依れば抗張力は高爐セメント最も大なれども耐髯力は最も小なり。即ち 酎捱力/抗 張力の比率(脆度係數)は高爐セメントは 10 以下、ソリヂチットはポルトランドセメントと共に 10 を越ゆ。本表のモルタルの强度は本邦最近のセメントのモルタルの强度に比すれば著しく小な 
りと踓も此の著しき進步は僅々二、三年のてとにして本報の試料は未だ進步著しからざりしとき のものなるは別報著者の本邦製セメントの試驗報告を参照すれば明らかなり。

\section{III セメントに對する酸液の侵蝕作用に關する比較試驗法}

セメントの酸液に對する抵抗性の比較試驗法に就ては之を純セメントに就て行ふも一方法なり 或はセメントモルタル又はコンクリートの如くセメントに砂、砂利を混用したるるのに就いて行 ふも一方法なり。然れども天然の溫泉水、地下水等の如く稀薄液に依りて隻刢を受ける速度は極 めて掘そたるものなるを以つて、本報に於ては之を短時日に作用せしめ其の作用を明暸に比較せ んがためセメントに砂を混用したる普通の强度試驗用 $1: 3$ モルタルに就いて $N / 10$ 又は 3/10 $N$ 溶液の如き天然には不自然をる濃厚の酸液を以つて其の侵蝕作用を比較試驗したり。此の方法 と類似したるものには虏にアイゼンベック氏(H. Eisenbeck, Chem. Ztg., 1926, 239.)其の他に依 りて探用したるものなり。

僤酸液としては先づ無機酸として硫酸及び鹽酸を探り、有機酸としては醋酸及び莎酸を選びた り。其の理由とするとてろはセメントに是等酸液の作用の結果最も多量に生成する石灰鹽の中硫 酸之葆酸との場合は水に不溶又は難溶性なる硫酸石灰。蓚酸石灰の生成が試驗片の表面に附着し て之を掩ひて作用を妨げ之に對して鹽酸及び醋酸の如く水に可溶性なる監化石灰、醋酸石灰の溶 出に依りて細隙を生じ其の作用は一層容易てして激しかるべきを豫想し得べきを以つてなり。

酸液の作用の比較研究法の大要は $1: 3$ モルタルの抗張力及び耐腛力試驗片を作り其の一部は 普通のャメント試驗規格に集じて水中に眝藏し、之之平行に他は $0.1 N, 0.3 N$ 等の稀酸性溶液中 に浸漬したものの兩者に就を其の强度を比較試驗し、侵蝕の模樣学檢したり。此の酸液に浸漬の 材缺命に就ては之を次の二樣に行ひたり。即ち試驗供試體成形後(甲)一畫夜濕空箱に型附の塧眝藏 したる後脫型し直ちに酸液に浸漬して普通の水中共生に依るものと同樣に成形後 1 週. 2 週.4週

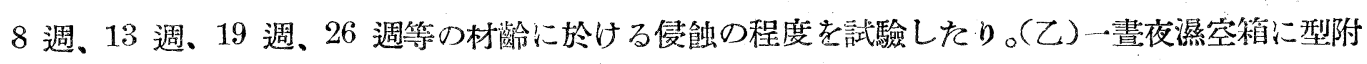
の㦈眝藏したる後脫型し普通 4 䢛試驗の如く水中に飨生するてと 4 週衙にて大部分の硬化を略完 了したる後水より引き出し酸液中に浸漬して成形後の日數を通算して 8 週、13 週、19週、26 週 等の材荼に於ける侵蝕程度を試驗したり。後節に記載する如く多くの酸液浸漬試噞は 19 週又は 26 週にして著しく侵蝕せらるるを以つて材龄は之を以つて充分なり。

試噞片を浸清する酸液はモルタルに對する作用の均一を計るた的隔日每に取り替へ又は其の一 部宛を新しくし且つ每日數回酸液を攪挥して試驗片て觸るる酸液を移動せしめ務めて作用を均一 ならしめたり。

抗張力供試體は酸液の作用により藏狀のくびれた次第に甚だしく抗張力試驗機にかけたる場合 は其の殘留せる實斷面に對する强度を得べく從つて强度は此の實斷面の單位面積に對する强度と 最初の $5 \mathrm{~cm}^{2}$ の面積に對する强度とに就いて求めたり。然れども耐壓力供試體は立方體の稜角 
に於て多く侵蝕せられ稍丸味を帶びをろ形となるを以つて是を耐厴力試驗機にかけたるものは主 として丸味の頂點のみにてて壓力を支へ其の强度は正當をる結果を與へ難きを以つて一、二包之を 行ひたるも主として抗張力試驗片に就んて專ら比較試驗したり。

\section{IV 硫酸液に依る侵蝕作用}

硫酸液は $0.1 N$ (約 $0.5 \%$ )液と $0.3 N$ (約 $1.5 \%$ )液との 2 種に就いて試驗し水中浸漬の標準試 驗結果と比較したり。

第四表 $0.1 N$ 硫酸液に依る抗張力比較試驗結果

セメント種别
浸清法侵蝕率
1 週
2 週
4 週
8 週
13 週
19 週
26 週

セメント種别

浸漬法侵触率

1 週

高爐セメント

\begin{tabular}{ccc}
\hline 水 & 酸液 & 侵蝕率\% \\
27.6 & 25.8 & 6.5 \\
30.3 & 29.9 & 1.3 \\
33.3 & 32.5 & 2.4 \\
36.2 & 31.3 & 8.5 \\
38.0 & 29.5 & 22.4 \\
39.1 & 26.7 & 31.7 \\
40.0 & 21.6 & 46.0
\end{tabular}

\begin{tabular}{ccc}
\multicolumn{3}{c}{ ソリダチット } \\
\hline 水 & 酸液 & 侵蝕率\% \\
26.5 & 25.9 & 2.3 \\
27.4 & 27.5 & 0 \\
23.7 & 25.6 & 10.4 \\
29.0 & 21.5 & 25.8 \\
30.1 & 16.2 & 46.2 \\
31.7 & 8.9 & 71.9 \\
32.6 & 1.9 & 94.2
\end{tabular}

\begin{tabular}{rrc}
\multicolumn{3}{c}{ 磐城セメント } \\
水 & 酸液 & 侵蝕率\% \\
25.0 & 26.7 & -6.8 \\
28.6 & 29.2 & -2.1 \\
32.1 & 31.2 & 2.8 \\
33.1 & 27.2 & 17.8 \\
34.3 & 23.2 & 32.4 \\
35.6 & 16.5 & 53.6 \\
36.8 & 8.1 & 78.0
\end{tabular}

第五表 $0.1 \mathrm{~N}$ 硫酸液に依る耐筀力比較試驗結果

2 週

4 週

8 週 高爐セメント

13週

19 週

26 週

\begin{tabular}{rrr}
\multicolumn{3}{c}{ 高爐せメント } \\
\hline 水 & 酸液 & 侵蝕率\% \\
254 & 216 & 14.9 \\
289 & 267 & 7.6 \\
326 & 288 & 11.7 \\
359 & 278 & 22.6 \\
370 & 259 & 30.0 \\
387 & 232 & 40.0 \\
392 & 194 & 50.5
\end{tabular}

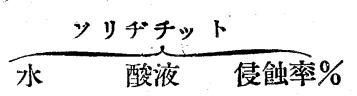

276

295

335

375

395

413

441

$250 \quad 9.4$

281

304

278

252

208

121

\begin{tabular}{rcc}
\multicolumn{3}{c}{ 硩城セメント } \\
\hline 水 & 酸液 & 侵蝕率\% \\
310 & 268 & 13.7 \\
350 & 319 & 9.1 \\
381 & 330 & 13.0 \\
402 & 315 & 21.6 \\
414 & 282 & 31.9 \\
425 & 244 & 42.6 \\
449 & 197 & 56.1
\end{tabular}

故に此の結果に依りて比較すれば耐壓力は抗張力に於けるよりる酸液の侵蝕少きは塊狀なるが そめなるてとは想像に難からず、然れどる 19 週.26 週等に於ては餘程丸味つものとなるを以つ て嚴格なる耐壓力と考へ難きを以つて向後は之を行はず、主として抗張力のみに就いて試驗した b。

是等 3 種の七メントの中高㠠セメントは最抵抗性大にして 26 週(約 6 ケ月)の終に於ては抗 張力、耐壓力共に酸液に浸潰したるものは水中に浸潰したるものの約牛分の强度を持續するに對 してンリヂチットに於ては最も著しく犯され、既に 19 週、26 週に於て抗張力殆んど無き迄に侵 蝕せり。ポルトランドセメントなる整战セメントに於ては其の信蝕の度合ソリヂチットよりは稍 少をけれども高爐七メントには及ばず。

抗張力試驗片の截斷部を檢するにソリヂチットは, 19 週。2 6 週間後のものも向大體の原形は保ち 居れども殆んど中心部に至る迄酸液に依りて犯され居るを認めたり。之れソリヂチットには花崗 


\section{第一圖 $0.1 \mathrm{~N}$ 硫酸液に依万侵蝕試験}

(1) 高爈セホント

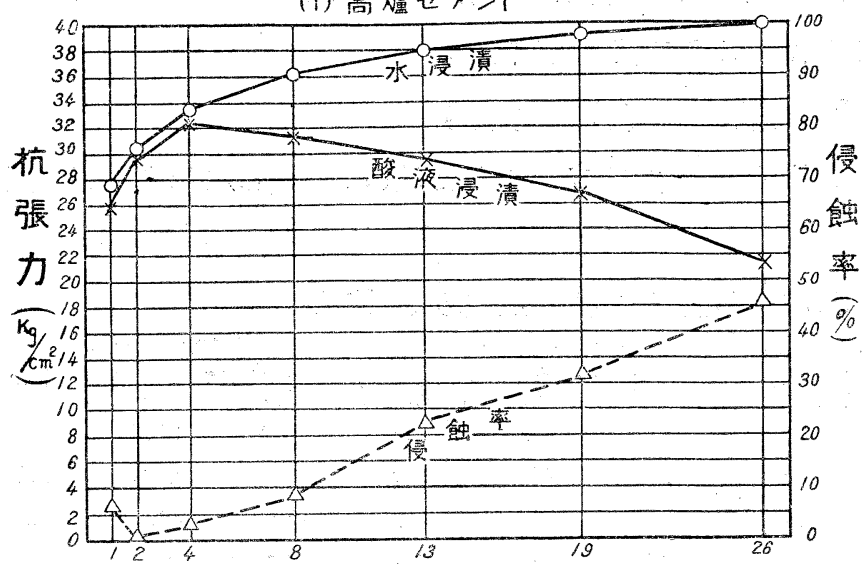

浸 漬 材 橧令(週)

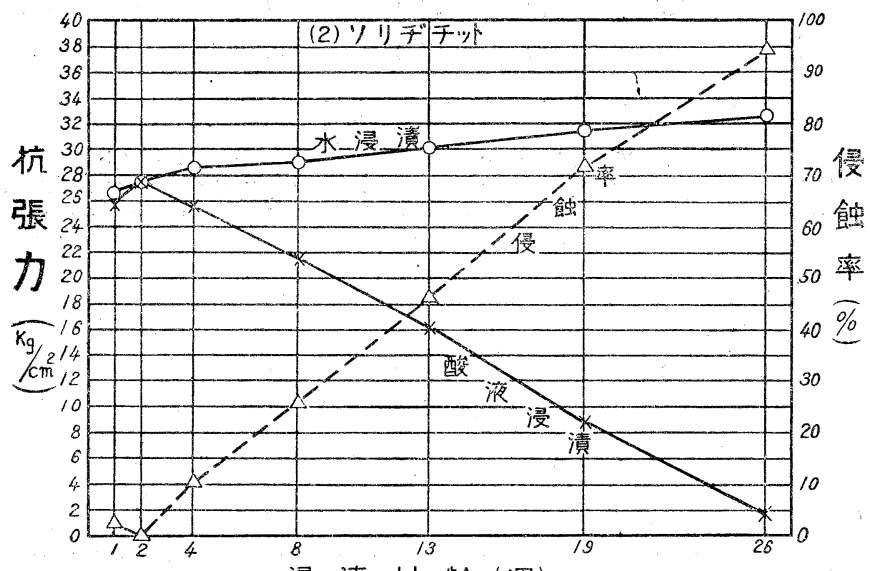

浸 漬 材 齢 (週)

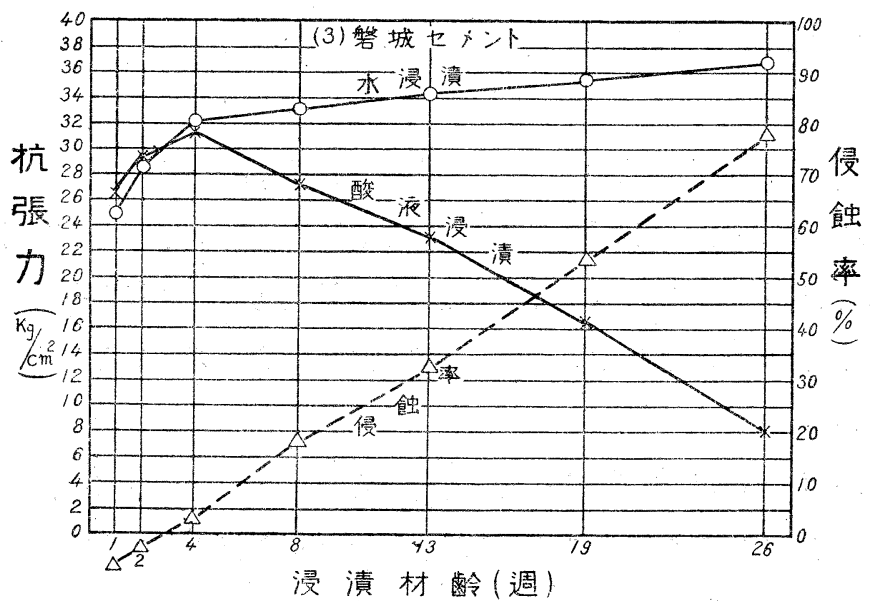

岩粉末の焙燒物の混入の䉆め、 此の混合物の大部分は單にもメ ントの稀稡物となり空㩐を生じ 易く從つて酸液の侵入を容易な らしめたるがためなるべし。 之に反してポルトランドセメ ントに於ては表面は白色てなり 截斷部を見るに內部迄侵蝕され をる模樣なく殆んど水中硬化物 の截斷部之同樣なり。之れボル トランドセメントには不灰分多 量にて硫酸に依りて硫酸カルシ ウムの愿き曆を生じて酸液の內 部への侵入を防ぐものの如し。 此の白色層は次第に制落して試 驗片は細り來る。

更に高爐セメントは表面は白 色となれども內部は殆んど侵搶 せられ和、而多表面の白色層は ポルトランドセメントの如く制 落することなく、試驗片に附着 して次第嵩ばり來るを認む。是 等の模樣は次節 $0.3 N$ 硫酸液に

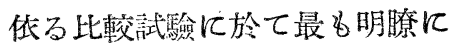
して第3 圖及び第 4 圖に於て其 の程度を比較し得へし。

更に前揭の第四表の絬果を第 一圖を以つて圖示すべし。

次には硫酸液を $0.3 N$ (約 1.5 \%)の稍濃き酸液となしたるも のを使用して其の他の條件は次 
そ述べるごとく 2 樣绅びて)にしたり。

（甲）成形後一書夜濕空称に貯藏し脫型後直ちに $0.3 N$ 硫酸液に浸湞したるものにて最初より

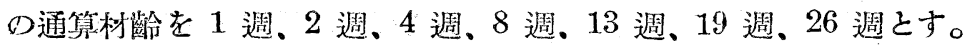

（乙）成形後一書夜濕空箱に館藏し脫型後 27 日間水中食生をなし即ち 4 週間普通つ水中硬化 に依り大體の硬化を終へたる後 $0.3 N$ 硫酸液に浸漬して最初よりの通算材齡 8 週、1 13 週.19週 26 週とす。

是等 $0.3 N$ 硫酸液の場合は前の $0.1 N$ 硫酸液の場合よりも酸液濃厚なるを以つてモルタルに對 する酸液の作用は一層激し。然るに他面に於ては酸液の濃度大なるが䈆めモルタルの表面に硫酸 カルシウムの生成量著しく、從つて密なる硫酸カルシウム被覆層の爲め冈部への酸液の隻入を妨 ぐるを以つて酸液の作用は單純には濃度のみに此例するものにあらざるべし。之は硫酸又は蓚酸。 炭酸の如き場合なれぎも後節の鹽酸。醋酸等の如く可溶性石灰鹽の生成の場合は自ら相異するも のなるべし。

前記の甲及び乙の兩場合の强度を相當する水中硬化强度に比舜して侵蝕率を求め得べく次の第 六表に就て是等の試驗結果を表示すべし。

\section{第六表 $0.3 N$ 硫酸液に依る抗張力比較試驗結果}

セメント種别

浸漬法侵飿萃

1 週

2 週

4 週

8 週

13 週

高爐セメント

$\overbrace{\text { 水 }}^{\text {高爐セメント }} \underset{\text { 酸液 }}{\text { 侵飿率 } \%}$

$\overbrace{\text { 水 酸液. }}^{\text {ソッヂチット }}$ 甲法 乙法 甲法 乙法 $\overbrace{\text { 水 酸液 }}^{\text {䑾城セメント }}$ 甲法 乙法 $\overbrace{\text { 甲法 乙法 }}$ $27.626 .8-2.9-26.524 .6-7.2-25.025 .1-27$ - 0 -

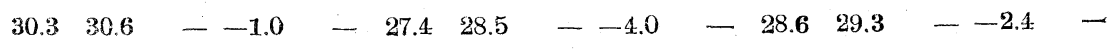
$33.329 .3-10.5-28.724 .9-13.2-34.124 .7 \quad-23.0-$ $\begin{array}{lllllllllllllll}36.2 & 27.3 & 38.3 & 24.6 & -6.9 & 29.0 & 22.9 & 26.5 & 21.0 & 8.6 & 33.1 & 21.7 & 30.6 & 34.4 & 7.6\end{array}$ $\begin{array}{lllllllllllllll}38.0 & 24.1 & 32.0 & 36.6 & 15.8 & 30.1 & 17.5 & 20.8 & 41.8 & 30.9 & 31.3 & 16.2 & 24.8 & 52.7 & 27.6\end{array}$ $\begin{array}{lllllllllllllll}39.1 & 17.7 & 25.9 & 54.7 & 33.8 & 31.7 & 11.9 & 14.6 & 62.5 & 53.9 & 35.6 & 10.1 & 18.3 & 71.6 & 48.6\end{array}$ $\begin{array}{lllllllllllllll}40.0 & 8.8 & 17.4 & 78.0 & 56.5 & 32.6 & 4.3 & 6.1 & 86.8 & 81.3 & 36.8 & 4.4 & 8.5 & 88.0 & \mathbf{7 6 . 9}\end{array}$

26週 故に此の結果に於ても高爐セメントは最も抵抗性大にしてンリヂチットと磐城セメントとは大 差なし。甲法の結果を前の第四表と比較する時は $0.3 N$ 硫酸液は $0.1 N$ 硫酸液より其の侵搶力著 しく大なら和。其の理由は暴に豫想したるが如く硫酸カルシウム被覆層の如何に化りて濃き酸液 が却つて其の優蝕作用を防げらるるがためなるべし。

更に第四表、第五表、第六表等に就て共通して認めらるる點は 1 週又は 2 週附近に於て酸液浸 漬物の强度が水中浸漬物の强度より稍大なるもの即ち侵刢率に頚號を附したるものなり。其の理 由とするとてろは硫酸カルシウムの被覆層のため內部へ水の參透を防ぎ何一般の水中硬化の水加 作用に依りて生成する水酸化カルシウムが水に依りて溶出せられて普通硬化が聯結硬化に劣る現 象に近似したる作用に依り强度が微かながら增大するが如をものと考へらる。第六表の結果を圖 示して比較すれば第二圖の如し。 
第二圖0.3N硫酸液に依了侵蝕試驗 (1) 高熘セたント
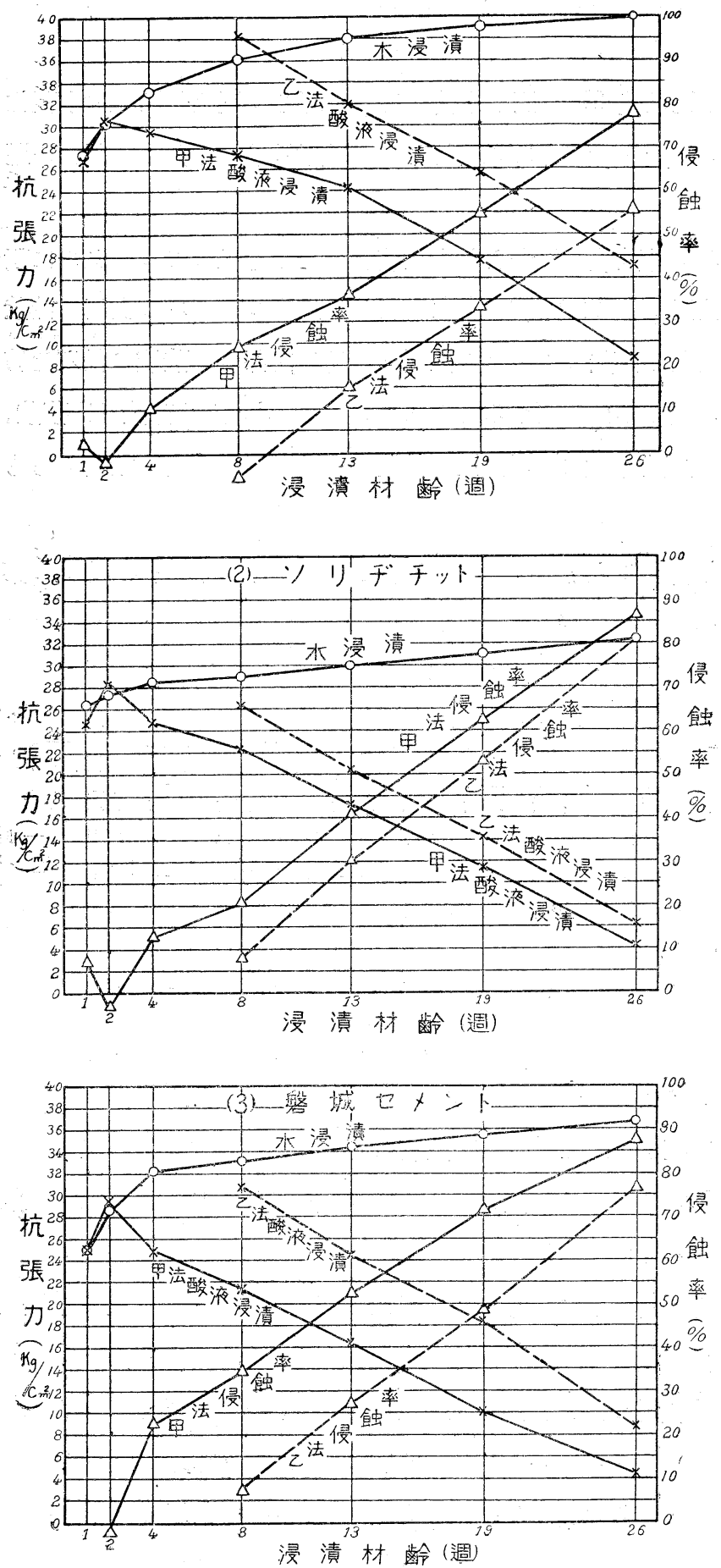

次に第六表の甲法 8 週間目に 於ける試驗片の $0.3 N$ 硫酸液に 依る侵刢の模樣を第三及び第四 圖に示すへし。前述の如く磐城 セメント最も著しく剥落しソリ ヂチット之に次ぎ、高爐セメン トに於ては剩落せすして禽ばみ たる白色層となりて殘れるを見 る。

次に第六表に於ける抗張力試 襝片の截斷部を試驗の都度之を 仔細に雚察するに第三圖、第四 圖の如く外㓺は硫酸カルシウム の白色㟲ありて內部に對する酸 液つ作用を妨げるを以つて中心 の截斷面は殆ん ゙氷中硬化物の 截斷面と變り無きものあり。故 几今、抗張力試驗の都度其の截 迦面の內部不侵搶部の 2 邊を測 定し置き其の面積を算出したる ๖のを以つて强度に耐へたる賔 面䅡として第六表の强度を此の 䁈面積に割り當てたる强度は次 の第七表に表示ずへし。此の結 果を水中硬化强度と比較對照す るととに依りて興味西る結諭を 得べし。 
第三圖（側面) $0.3 N$ 硫酸液に 13 週間浸漬

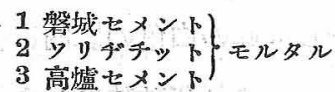

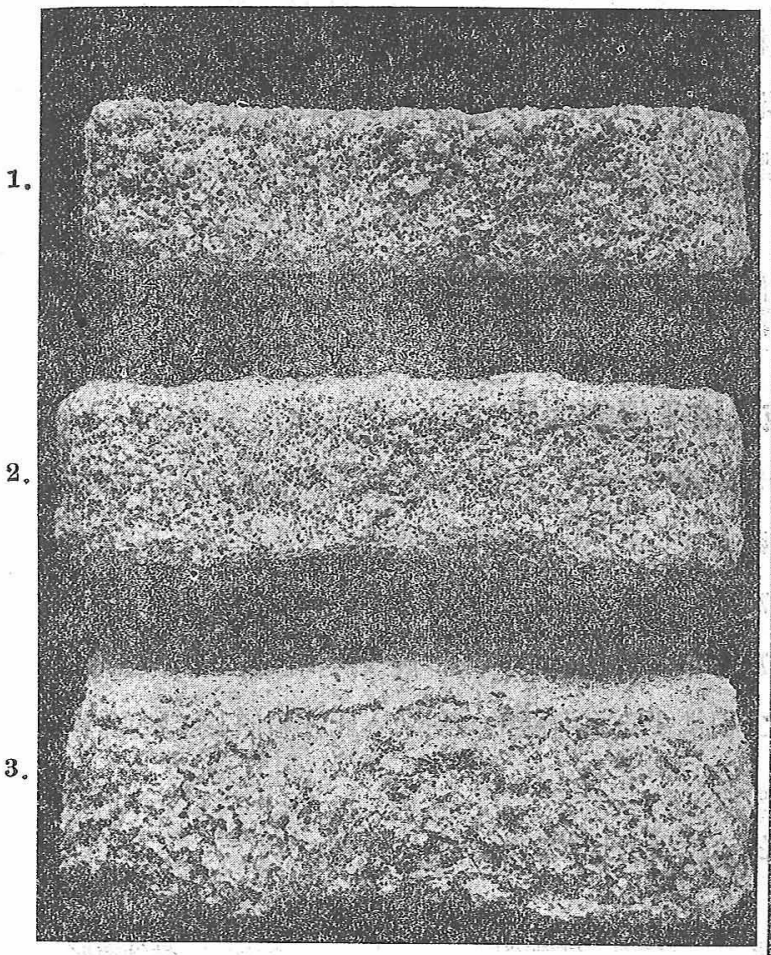

第 4 圖 (平面) 第三圖に同じ

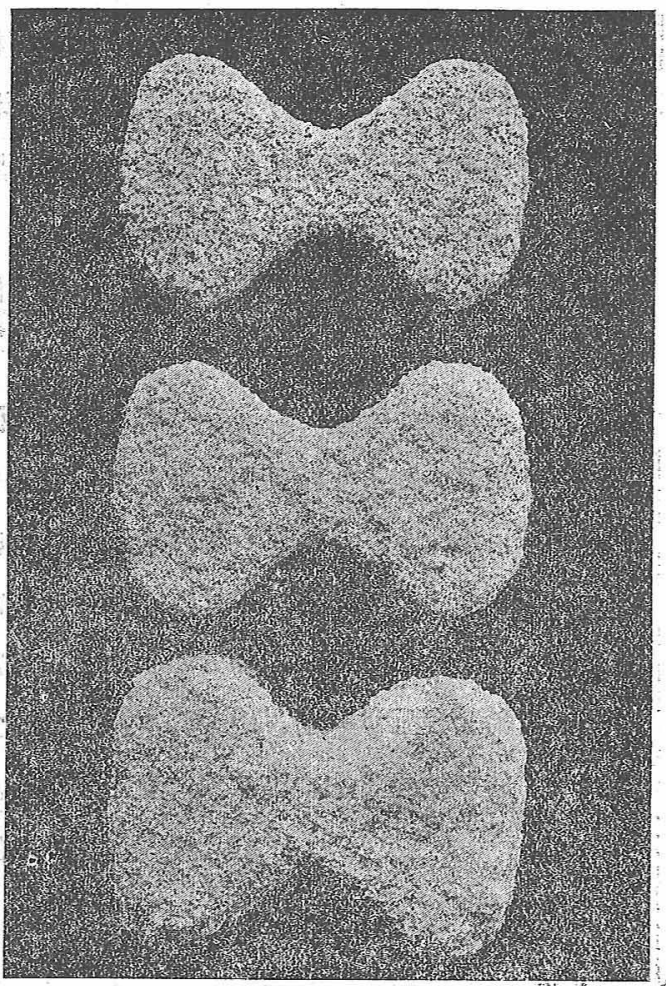

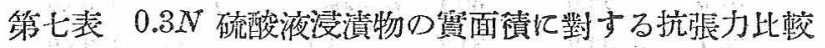

\begin{tabular}{|c|c|c|c|c|c|c|c|c|}
\hline \multirow[t]{3}{*}{ セメント種别 } & 浸漬法實面積强) & 1 週 & 2 週 & 4. 週 & 8 遇 & 13 過 & 19 週 & 26 週 \\
\hline & 實面積 (訶法 & 4.96 & 4.94 & 4.36 & 3.76 & 3.13 & 2.18 & 1.06 \\
\hline & $\left(\mathrm{cm}^{2} ，\right.$ 亿法 & - & - & - & 4.96 & 4.24 & 3.27 & 2.06 \\
\hline \multirow[t]{5}{*}{ 高笽セメント } & 酸 液 $\{$ 甲法 & 27.0 & 81.0 & 34.2 & 36.3 & 38.5 & 40.6 & 4.1.5 \\
\hline & 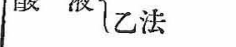 & - & - & - & 38.6 & 37.8 & 39.6 & 4.0.3. \\
\hline & 水 & 27.6 & 30.3 & 33.3 & 36.2 & 38.0 & 39.1 & 40.0 \\
\hline & 實面責（甲法 & 4.93 & 4.89 & 1.58 & 4.10 & 2.95 & 1.94 & 0.74 \\
\hline & $\left(\mathrm{cm}^{2}\right)$ 亿法 & - & - & - & 4.63 & 3.57 & 2.53 & 1.59 \\
\hline \multirow[t]{5}{*}{ クリヂデント } & 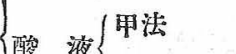 & 24.9 & 28.1 & 27.2 & 27.9 & 29.7 & 30.7 & 29.1 \\
\hline & 毁议记法 & - & - & - & 28.6 & 29.1 & 29.0 & 19.5 \\
\hline & 水 & 26.3 & 27.4 & 28.7 & 29.0 & 30.1 & 31.7 & 32.6 \\
\hline & 賽面積，早法 & 4.61 & 4.92 & 3.92 & 3.52 & 2.31 & 1.43 & 0.61 \\
\hline & $\left(\mathrm{cm}^{2}\right)$ 亿法 & - & - & - & 4.62 & 3.16 & 2.59 & $1.17^{*}$ \\
\hline \multirow[t]{3}{*}{ 醔战セメント } & 臹 液 & $25 . \frac{8}{2}$ & 29.8 & 31.5 & 33.9 & 35.1 & 35.3 & 36.1 \\
\hline & 细 亿法 & - & - & - & 33.3 & 35.8 & 35.3 & 36.3 \\
\hline & 水 & 25.0 & 28.6 & 32.1 & 33.1 & 34.3 & 35.8 & 36.8 \\
\hline
\end{tabular}


即ち此の結果は比較的よく一致し、從つて稍濃厚㩼る硫酸液に依りては硫酸カルシウムの白色 の緻密なる被㠅層の䉆めに酸液の侵玲作用は內部に及ばすして此の白色の層內に包まれたる筫面 積に對する强度は水中硬化の强度と大差なし。即ち此の結果に依れば硫酸の如き不溶性石灰監を 形成するものに於ては外部の被覆層を生じて機械的に此の被覆層の佂脫を行ふにあらざれば酸夜

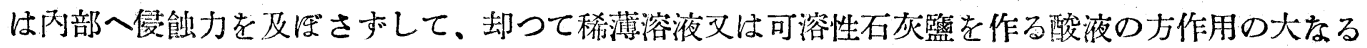
べきを想像せしむ。是等は後節に於て監酸、醋酸等を以て研究せんとす、ソリヂチットの場合江何 れも賽面積に對する强度は水中强度より小にして特に乙法の 19 週、26 週、に於て著しきてとは 前述せる如くソリヂチット中の混和物なる花愬岩焙燒物粉末が單に稀釋物となり酸液の內部侵蝕 作用に容易なるが篇めなるべし。

\section{V 鹽酸液に依る侵蝕作用}

鹽酸、确酸の如く可溶性石灰監を形成すべき酸液のセヌントモルタルに對する侵蝕作用は前節 の硫酸液に依るものとは自ら相異するとてろあるべし。本節に於ては監酸刀 $0.1 N$ (約 $0.37 \%$ ） $0.3 N$ (約 $1.1 \%$ ) 液を以つて比較試驗をなしたり。浸漬法は乙法に低るものにして試驗片は 4 週 䦌普通の水中硬化をなし大部分の硬化をなしたるものに就いて、其の後酸液に浸漬して最初より の通算材㳇 8 週、13 週、19 週、26 週に於て相當する水中硬化の强度と比較對照して侵蝕率を 見たり。其の結果を次の第八表に表示すべし。

第八表 鹽酸液に依る抗張力比較試驗結果

セメント種别
浸漬法侵蝕率
8 遇
13 週
19 週
26 週

$\begin{array}{rcc}\text { 水 } & \text { 酸液 } & \text { 侵蝕率\% } \\ 36.2 & 37.0 & -2.2 \\ 33.0 & 31.9 & 16.0 \\ 39.1 & 26.1 & 33.2 \\ 40.0 & 17.5 & 56.2\end{array}$

\begin{tabular}{crr} 
水 & 酸液 & \multicolumn{1}{c}{ 侵蝕率\% } \\
29.0 & 29.5 & -1.7 \\
30.1 & 24.9 & 17.3 \\
31.7 & 19.9 & 37.2 \\
32.6 & 12.2 & 62.6
\end{tabular}

\begin{tabular}{|c|c|c|}
\hline \multicolumn{3}{|c|}{ 槃城七メント } \\
\hline 水 & 酸液 & 侵飿率 \\
\hline 33.1 & 32.6 & 1.5 \\
\hline 38.3 & 27.0 & 21.2 \\
\hline 35.6 & 23.8 & 33.1 \\
\hline 36.8 & 13.3 & 63.8 \\
\hline
\end{tabular}

即ち此の結果安第六表の乙法に於ける $0.3 N$ 硫酸液の作用之比較すれば監酸は $0.1 N$ 液の稀薄 液にても充分强く作用し硫酸の $0.3 N$ 液と殆んど一致する作用を呈せり。向高盧セメントは 3 種 の中にては稍抵抗性大なれども殆んど大差なし。

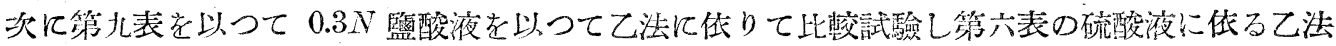
の結果と比較して鹽酸と硫酸とが同一濃度に於て隻刢作用に如何程の差異西るかを比較せんとす 第九表 $0.3 N$ 監酸液几依万抗掁力比較試驗結果

\begin{tabular}{|c|c|c|c|}
\hline セメント種别 & \multicolumn{3}{|c|}{ 高爐セメント } \\
\hline 浸清法侵刢率 & 水 & 酸液 & 侵蝕率\% \\
\hline 8 週 & 36.2 & 28.0 & 22.6 \\
\hline 13 週 & 38.0 & 22.7 & 40.2 \\
\hline 19週 & 39.1 & 15.1 & 61.4 \\
\hline 26 遇 & 4.0 .0 & 9.7 & 75.7 \\
\hline
\end{tabular}

\begin{tabular}{|c|c|c|}
\hline 水 & 酸液 & 侵飿率\% \\
\hline 29.0 & 24.8 & 14.4 \\
\hline 30.1 & 19.2 & 36.2 \\
\hline 31.7 & 11.2 & 61.7 \\
\hline 32.6 & 5.3 & 83.7 \\
\hline
\end{tabular}

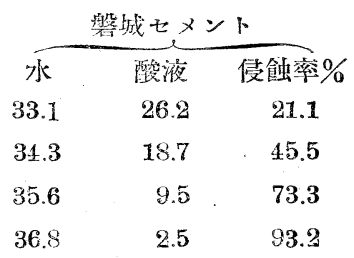


䍃五圖塧酸液に依る侵蝕試驗
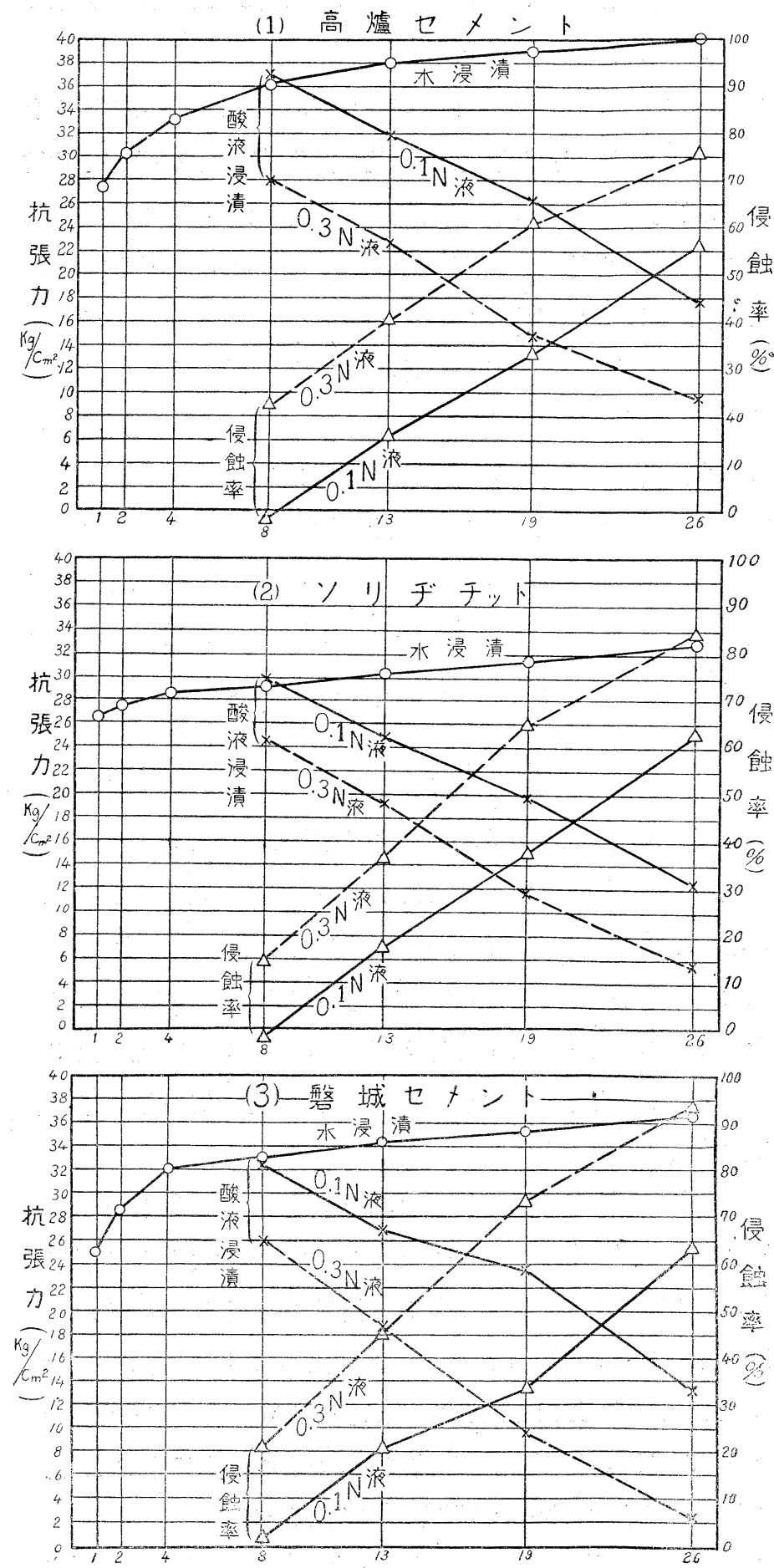

浸清初 路令(涸)
即ち此つ結果に低れば監酸つ 信刢は硫酸の夫れに於けるより も激しくポルトランドセメント なる磐城セメントに於て最も著 しきbのなり。然して硫酸の場 合の如く白色被㠅㽧の保護に依 り 8 週酸液浸漬物が水中浸漬物 よりも却つて强度稍大なりしが 如きことなく 8 週より直ちに强 度の減少著しきものあるは豫想 したるが如く監化カルシウムが 水に溶出せられ內部二の作用大 なるに依るものなり。此の點は ソリヂチット、高盧セメントが 19 個又は26個の試驗片の截斷面は 相當に大なる面積を有しながら 强度著しく小にして截㶌面の內 部迄酸液に充分犯されたる跡を 認め得べき事䁈より明確に證明 し得べきものなり。

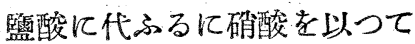
之它行ふも略及同樣なるへく㶵 機酸に關する比較試驗は之に止 め次報に於て寽機酸に依る作用 の比輘研究を報告すべし。向ポ ルトランドセメントが是等酸液 飞對する抵抗性最も小なる缺點 を補はんがをめ特别混和物の 便用に低りて强度には餘り減退 を來すことなく、是等酸夜に對 する抵抗性索高盧七メントの夫 
れに匹敵し或は夫れ以上たらしめ得べき結果を得つっあるを以つて次報に於て之を報告せんとす

\section{VI 總}

\section{括}

本邦製混合セメントの 2 種高盧セメント及びンリヂチットとポルトランドセメントの 1 種とを 試料として是等 3 種のセメントモルタルル對する無穖酸及び有機酸の稀薄酸液の傢玲作用を比較 研究せんとし本報は其の第一報として無機酸液に對する比較研究結果を報告したるものなり。

高爐セメントはアルミナセメントに次いで監類溶液に抵抗性大なるものとせられ、高爐セメン トは我が八幡製鐵所に於て近來漸く優秀なるものの大量の製產を見つ」すり。且づッリヂチット も亦本邦に於て製造せられつ১ある特殊の混合セメントなりり。本報の目的は是等の特殊セメント と普通のポルトランドセメントが酸液、鹽類液、アルカリ液等に對する抵抗性に如何程の優劣あり や它究め、進んで是等混合セメントの製造條件が强度に於て普通のポルトランドセメントと競ふ の外に夫等混合セメント獨特の點に於いて果して最も適虽なりや否やを知らんとするも其の目的 のー・寺り。晌又ポルトランドセメントが是等混合セメントに對して酸、アルカリ、鹽類液に對す る抵抗性に於て劣るとてろありとすれば、之を如何にして補正し得べきか、即ち適虽の混和物の 使用に依りて高㠠セメントに劣らざる抵抗を有せしめ得べしと信和るを以つて、之が研究を進め つおあるも亦其の目的の一なり。

本報に於ては無機酸の中セメントの水硬素なる石灰監と作用して水に難溶性監古作る硫酸と。 可溶性鹽を作る鹽酸とを取り、其の濃度を $0.1 N$ と $0.3 N$ との 2 種の酸液として之に 3 種のセメ ントモルタルの抗張力及び耐壓力試驗供試體を浸漬して其の隻刢力を比較研究したり。其つ浸清 法は甲法と乙法の 2 種を取りたり、即ち甲法は試驗片成形一畫夜後直ちに酸液に浸湞したるもの とし、乙法は 4 週間普通の水中養生をなし大部分の硬化をなしたる娞酸液に浸湏したるものとて して、試驗材龄は成形後通算材齡を 1 週. 2 週. 4 週. 8 週. 13 週. 19 週. 26 週(乙法は 8 週13 週. 19,26 週) としたり。是等の結果を相當する材䍅の水中硬化物の强度と比較して酸液 の隻玲程度を見たり。本報に於ける試驗結果の概要次の如し。

(1) 硫酸液の作用は $0.1 N$ 液と $0.3 N$ 液との濃度の差異に比例する程に侵触作用は相違せず。 其の理由は硫酸液に依りて生成せる水に難溶性の硫酸カルシウムが試驗片の表面に緻密应る白色 被覆層をなして內部へ酸液の侵入を妨ぐることは $0.3 N$ 液に於て一層著しきが䉆めなるべし

（2）硫酸液に於ては水中硬化物より住ににして强度大なるものあり。例へば甲法に於て 1 週間 又は 2 週間目、或は乙法に於て 8 週間目のものは水中硬化物の强度に優るか殆んど同等の强度を 有するものなり。其の理由る（1）の場合と同じく水に難溶なる硫酸カルシウムの被覆層のため內 部に對する酸液の作用を防ぎ、更に水に依る石灰の溶出をる防ぐが爲めなるへし。

（3）硫酸液に低る白色被覆層のため內部迄酸液の隻入を妨け゚て、强度の減退の小なるを證明す

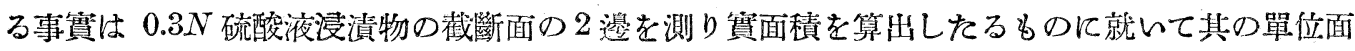


積に對する抗張力を算出したるものは水中硬化物の强度と極めてょく一致し寧ろ稍大なる數值を 與ふる結果に依りて極めて明確なり。

（4）鹽酸液に依る作用は相當する濃度の硫酸液に依るものよりも著しく、即ち同じく乙法に依 りて比較すれば $0.1 N$ 監酸液と $03 N$ 硫酸液と殆んど等しく $0.3 N$ 鹽酸液の作用最も著し、鹽酸 液つ場合は水に可溶性なる監化カルシウムの雼め水に溶出したる細吵より酸液の侵入、浸蝕を續 け得るが䉆めにして試驗片の截斷面は相當に大なるに拘らず、强度の小なる事實は之を確證する タのなり。

(5) 是等酸液の侵蝕試驗は主として抗張力試驗片に就いて行ひ、耐壓力試驗片に就いては數四 行ひたるも侵玲につれて丸味を生じ再度試驗に不適當なりしを以つて深く行はず。

（6）甲法に依りて得たる强度は常に乙法に依れるものよりも小なり。其の理由は自ら明白にし て甲法は未だ硬化の充分進すざる2 日目より既に酸液に浸湏するに對し、乙法は略了硬化の大體 を完了したる 4 週間の後酸液に浸漬するものにして倘同じ 8 週、13 週等に於てタ甲法は乙法よ りも常に 27 日宛長く酸液に浸漬せられて居るものなり。然れども(3)の硫酸液浸漬の場合截斷 面の賽面積心割り當てたる强度が甲法、乙法及び氷中浸瀆の何れに於てる大差なき事䔈は硫酸液

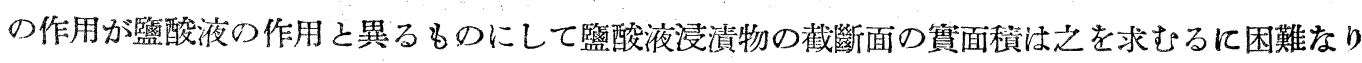

(7)是等 3 種の七メントに於いて考ふれば一般に高爐セメント最も强くソリヂチット、ポルト テンドセメント之に次ぐ。然して高爐セメントに於ては酸液浸瀆物が其の表面の酸液の䴇め几生 じたる被覆物層の㓿落少きに對してポルトランドセメントに於ては浸湏せらるつに從つて制落し 急に細り來るの相異西り之は高爐七メントの製造に於てクリンカーに加ふべき監基性鍰滓に因る ものなるべく、ソリヂチットは花岗岩の焙燒粉末の混合なるを以つて其の大部分は殆んど不活性 の稀釋物たるに過ぎざるのっ如く酸液に對する抵抗性はポルトランドセメントに優るとてろ败 著ならす。花崩岩熔燒粉未以外に何等か一層有效にして適當なる混合物あるべしと信亦。

（8）高爐セメントの抵抗性がポルトランドセメント、ソリヂチットに對して優れたる程度は決 して大なるものにあらず。況んや最近の高爐セメントの如く、クリンカーに對する龲滓の量を減 少して沿んど鐵ポルトランドセメントと大差なきが如き高爐セメントに於ては普通の强度のみは 幾分の增進を期し得べきも、别に高爐セメント獨特の諸點が主として滓鑕の相當量の混用に依り てのみ望み得べしとすれば鐄涬の混用量を著しく減少せしめ殆んど鐵ポルトランドセメントと何 等異らさるが如き高爐セメントは果して高爐セメントとして炃當なるものなりや疑無き能はざる るのなり。

佾著者はポルトランドセメントに或る適當なる混和物を使用すれば其の强度に於ては少しも害 するてとなく酸液、鹽類液等に對する抵抗性等に於ては高爐セメントに優る迄に改善せらるつを 究めたるを以つて次報以下に於て報告すべく此の點より見るも高纑セメントは單に普通の强度の 
みに於て普通のポルトランドセメントと競ふべきものにあらずして他に高爐セメント獨特の製造 方針を有すべきなり。

終に本研究に對し助手佐藤政男、弘籍好人兩君の熱心なる助力を受けたるもの多し。著は垚に 厚く謝意を表するものなり。(㫢和三年五月十五日) (東京帝國大學工學部應用化學科無機工業化 學研究室)

\section{セメントの限産緩和決議}

セメント聯合會は八月十三日より十七日まで恒例通り 大阪で集會を催した、十五曰大阪大江ビルに於ける第二 委員會席上で九月以降十一月までの生產制限几關し審議 した結果限產緩和をはかることつし左の如く決議した。 昭和三年九月。十月。十一月の三ヶ月閔性生產制限率 を九月。十月最高二割六分。十一月最高三割（九月百

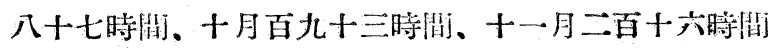
平均二割七分三厘）とし、乙れに生產制限に適用すへ き特定制限率を乘じ各工場の休轉時缼を短縮し生產制 限老行ふ心为のす。

右の決議により今期の限產率は前期の限產率最高三割 二分に比べれば兀、十兩月牥六分、十一月は二分の限產 緩和をはかるてとつなつたわけである。 